\title{
Protective Effect of Human Menopausal Gonadotropins on Rat Ovarian Structure Following Use of Nandrolone Decanoate: From a Histological Standpoint
}

\author{
Hossein Bordbar ${ }^{1}$, Afsoon Bordbar ${ }^{2}$, Farzaneh Golfeshan $^{3}$, Ebrahim Rahmani Moghadam ${ }^{4}$
}

1. Assistant Professor, Histomorphometry and Stereology Research Center, Department of Anatomical Sciences, Medical

School, Shiraz University of Medical Sciences, Shiraz, Iran. ORCID ID: 0000-0003-0363-9523

2. Dentist, Department of Dentistry, School of Dentistry, Shiraz University of Medical Sciences, Shiraz, Iran. ORCID ID: 0000-0001-7508-7057

3. Assistant Professor, Department of Orthodontics, School of Dentistry, Shiraz University of Medical Sciences, Shiraz, Iran. ORCID ID: 0000-0001-8484-5593

4. MSc. of Anatomical Sciences, Department of Anatomical Sciences, Medical School, Shiraz University of Medical Sciences, Shiraz, Iran. (Corresponding author), Email: e_rahmani@sums.ac.ir, Tel: +98-71-32304372,ORCID ID: 00000003-3610-3311

\begin{abstract}
Background and Aim: Nandrolone decanoate is known as one of the most destructive environmental factors in the reproductive system in men and women. In this study, we assessed the protective effect of gonadotropins (hMG) on histological changes of rat ovarian structure.

Materials and Methods: 50 female rats were divided into 5 groups, including control, nandrolone decanoate (ND), hMG, ND + hMG, and sham group $(0.1 \mathrm{ml}$ of olive oil and $0.1 \mathrm{ml}$ sodium chloride $0.09 \%$ ). After 4 weeks, qualitative histological studies were performed, and the total volume of ovarian vessels was estimated by stereological methods.

Results: Nandrolone decanoate increased the mean volume of vessels $(66 \%)$ and the use of hMG + ND led to an increased mean volume of vessels (83\%) compared to the use of $0.1 \mathrm{ml}$ of olive oil and $0.1 \mathrm{ml}$ sodium chloride $0.09 \%$ (sham group) ( $\mathrm{P}<0.001$ ). Histological studies showed induction of ovarian cysts in ND treated group and the administration of hMG + ND decreased follicular damage.

Conclusion: Nandrolone decanoate increased the total volume of ovarian vessels and induced histological changes in ovarian tissue. The use of hMG with ND increased the total volume of ovarian vessels and prevented the harmful effects of ND on ovarian follicles.
\end{abstract}

Keywords: Human menopausal gonadotropins, Ovary, Nandrolone decanoate, Rat

Received: May 23, $2019 \quad$ Accepted: July 15, 2020

How to cite the article: Hossein Bordbar, Afsoon Bordbar, Farzaneh Golfeshan, Ebrahim Rahmani Moghadam. Protective effect of human menopausal gonadotropins on rat ovarian structure following use of nandrolone decanoate: From a histological standpoint. SJKU 2021;25(6):1-9.

Copyright $\odot 2018$ the Author (s). Published by Kurdistan University of Medical Sciences. This is an open access article distributed under the terms of the Creative Commons Attribution-Non Commercial License 4.0 (CCBYNC), where it is permissible to download, share, remix, transform, and buildup the work provided it is properly cited. The work cannot be used commercially without permission from the journal 


\section{اثر محافظتى تونادوتروبين يائسكى انسانى بر ساختار بافتى تخمدان موش صحرايى به دنبال

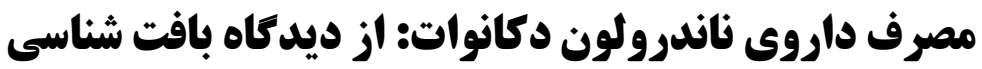

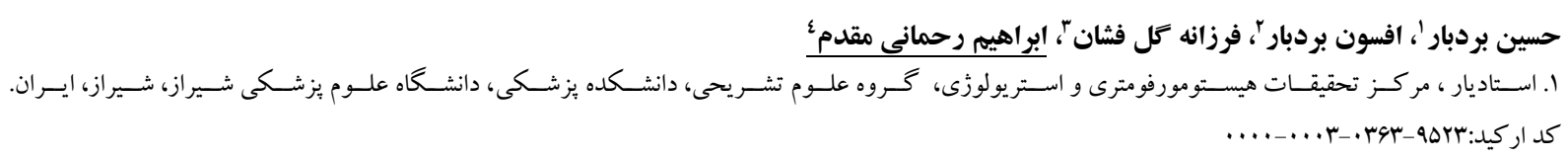

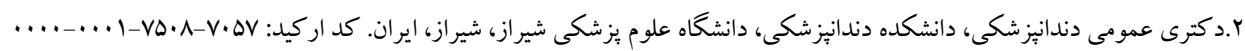

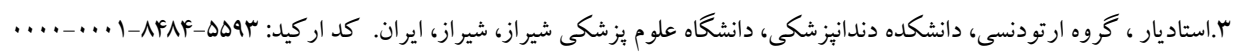

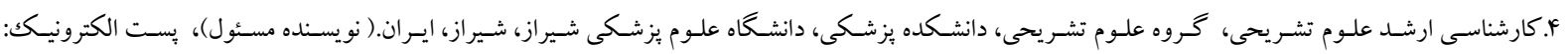

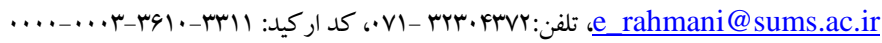

جكيuه زمينه و هدف: مصرف بى رويه داروى ناندرولون دكانوات به عنوان يكى از عوامل محيطى مخرب بر دستخاه توليد مثل در

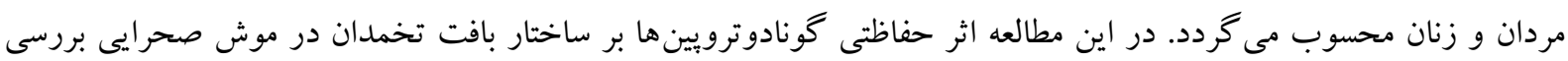

مواد و روشها: در اين مطالعه ·ه سر موش صحرايى ماده، به ه گروه ده تايى شامل گروه كنترل كه هيج دارويى دريافت

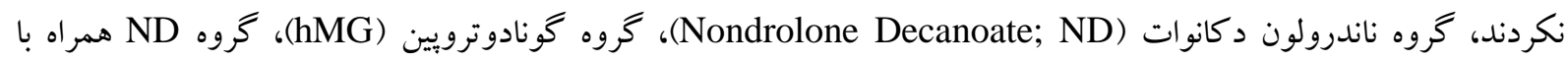

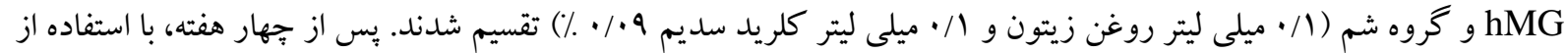
روش هاى استريولوزى، حجم كل عروق خونى تخمدان محاسبه و همجينين مطالعات كيفى هيستولوزيكى انجام شد. يافتهها: مصرف داروى ND باعث افزايش ميانگين حجم عروق خونى (94\%) و استفاده همزمان داروى ND با داروى hMG

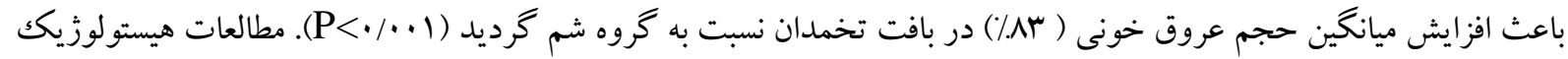
نشان داد كه داروى ناندرولون دكانوات باعث القاى كيست تخمدان و افزايش حجم عروق خونى در تخمدان شده و مصرف همر اه با ناندرولون د كانوات باعث كاهش صدمات فوليكول هاى تخمدان مىشود. نتيجه كيرى: داروى ناندرولون دكانوات باعث افزايش حجم عروق خونى و تغييرات هيستولوزيك در بافت تخمدان مى شود . اين مطالعه نشان داد كه داروى hMG همراه با ND علاوه بر افزايش حجم عروق خونى، از تغييرات زيانبار در بافت تخمدان جلو كيرى مى كند. وازههاى كليدى: گونادوترويين يائسگى انسانى، تخمدان، ناندرولون دكانوات، موش صحرايى

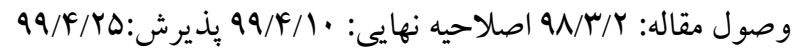


داروها، ناندرولون دكانوات مىباشد. مصرف اين داروها در بين زنان در طولانى مدت مى تواند باعث بروز عوارضى

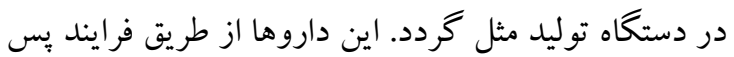

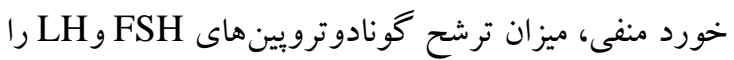
كاهش داده و بدين ترتيب بر ساختار بافت شناسى تخمدان،

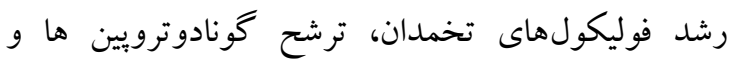

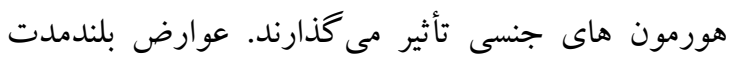
داروهاى استروئيدى هنوز بهصورت كامل در زنان شناخته نشده است؛ و اين عوارض در زنان، بر خلاف مردان،

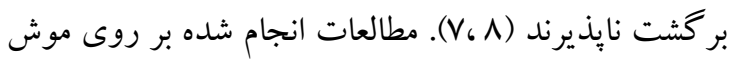
صحرايى ماده نيز نشان داده است كه داروهاى نيروزا با اثر

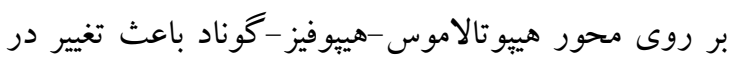
ترشح هورمونهاى مترشحه از هييوتالاموس و غدهى

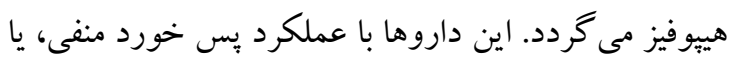
با اثر مستقيم روى هييوتالاموس، باعث كاهش ترشح هورمون آزاد كننده گونادوترويين (Gonadotropin-) Releasing Hormone; GnRH و كاهش رشد فوليكولهاى تخمدان مىشود (•169). در مواردى كاهش استروماى آندومتر و فقدان سيكل استروس به دنبال مصرف اين داروها گزارش شده است. مصرف طولانى داروهاى نيروزا، همراه با اثرات طولانى اين داروها، فرصت بازسازى را از بافت رحم گرفته و اين منجر به كاهش ضخامت آندومتر و افزايش ضخامت ميومتر مى گردد (1) (96).

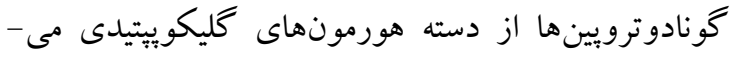
باشند كه نقش اساسى در تكامل فوليكول هاى تخمدان را به عهده دارند. اين هورمون ها داراى گيرنده هاى اختصاصى در بافت تخمدان بوده و باعث افزايش گيرنده ها هائ

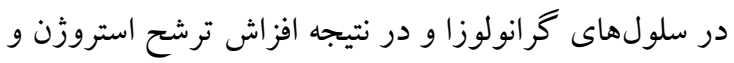

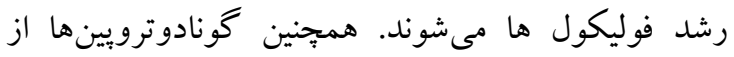
طريق افزايش بيان فاكتور رشد اندوتليوم عروق خونى دمن درنين افزايش خونرسانى به فوليكول ها نيز نقش دارندكه نقش اساسى در تكامل فوليكولهاى تخمدان به عهده دارند(r). رشد فوليكولها نتيجه فرايندهاى يس خورد دردئ مثبت و منفى

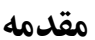
مهم ترين هدف توليد مثل به عنوان يكك فرايند بيولوزيكى،

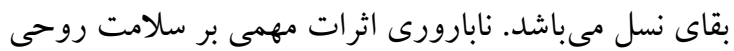
و روانى فرد دارد و مى تواند زمينهساز مشكلات زيادى از

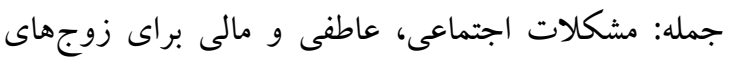
جوان باشد. عوامل مختلفى در بروز نابارورى در مردان و

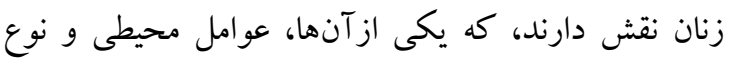

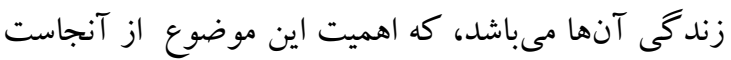

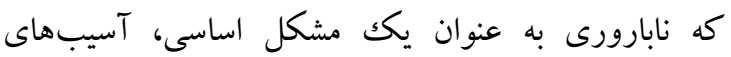

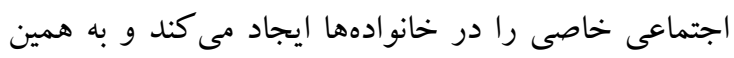
دلايل توجه محققين زيادى را به خود جلب كرده

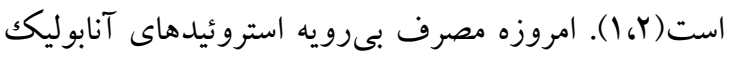
آندروزنيك ) Anabolic-Androgenic Steroids; (AAS به به عنوان يكى از عوامل محيطى، تاثيرات فراوانى را

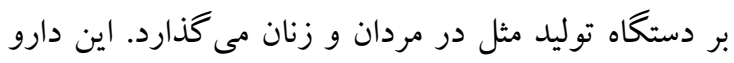

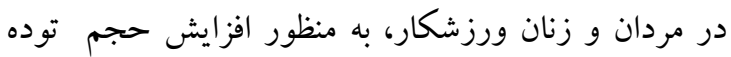
ماهيجهاى مصرف مى شود؛ در حاليكه افراد غير ورزشكار به منظور تناسب و زيبايى اندام، جنبهاى روحى-روانى و افزايش اعتماد به نفس، از اين داروها استفاده مىنمايند؛ و از اين راه، علاوه بر عوارض جانبى فراوان و برخطر، هزينههاى سنگينى را به خود و جامعه تحميل مىنمايند (F) (F). استفاده از داروها و مواد نيروزا نه تنها در بين افراد ورزشكار، بلكه در افراد غير ورزشكار نيز رواج يافته است؛ و اكثر افراد

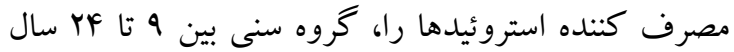
تشكيل مىدهند. همجِين بر طبق آمار در حدود F تا 4

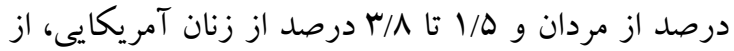
اين تركيبات دارويى استفاده مى نمايند. ايران نيز در شمار كشورهايى است كه مصرف داروهاى استروئيدى در آن

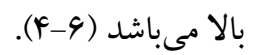
داروهاى AAS، تركيباتى صنعتى شبيه آندروزنها بوده و هماند هورمونهاى جنسى مردانه عمل مى كنند كه در

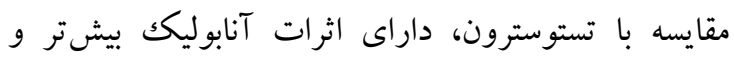

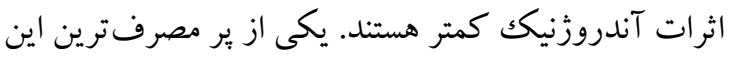


مدت جهار هفته، يكك بار در هفته تزريق شد. در گروه سوم

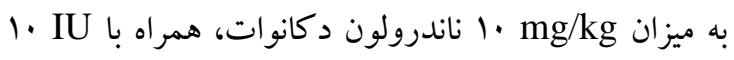
داروى hMG به صورت داخل صفاقى به مدت جهار هفته،

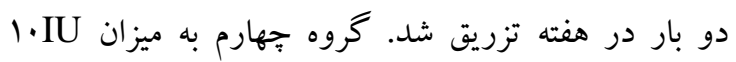

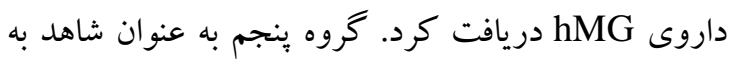

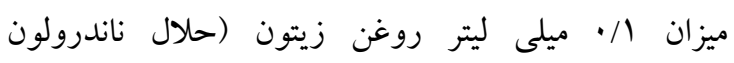
دكانوات) و / • ميلى ليتر كلريد سديم 9.

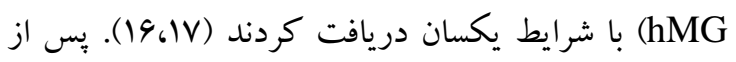
جهار هفته، موش ها تحت بيهوشى عميق كشته شدند و

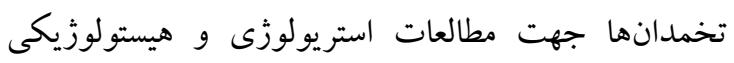
برداشته شدند. بِ از برداشتن تخمدانها، به منظور بررسى - مانى

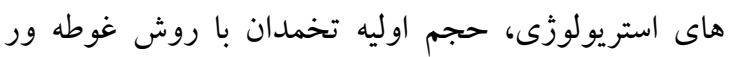

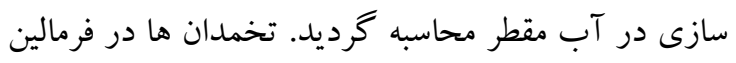
•ا درصد ثابت شده و مر احل يردازش بافتى بر روى نمونه-

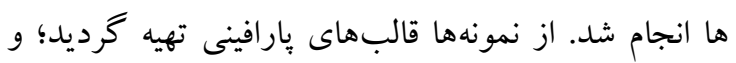

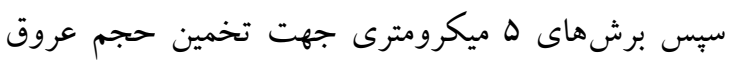
خونى تهيه شد. مطالعـات كيفى بافت تخمــان: بـه منظور بررسى كيفى تغييرات بافتى درساختار تخمدان، بـرشهـاى هـ ميكرومترى بهرى

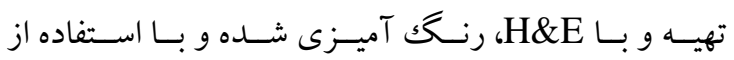
ميكروسكوبٍ نورى مورد بررسى قرار گر فتند. محاسبه دانسيته حجمى و حجم كل عروق خـونى تخمـدان:

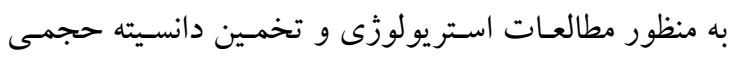
عروق خونى تخمدان، برشهاى سريالى ه ميكرومترى تهيـه

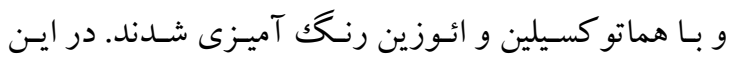

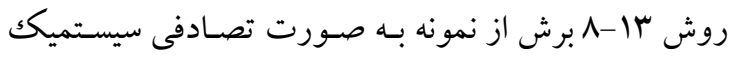

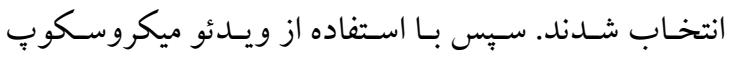
SONY, (Nikon, E-200, Japan) متصـل بـود، بـا قـرار دادن يـك دونك (SSC Dc 18P, Japan

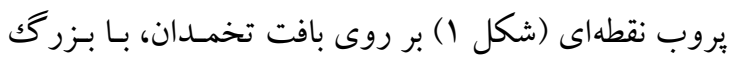

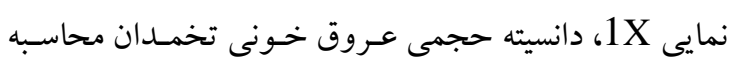

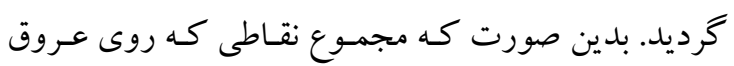

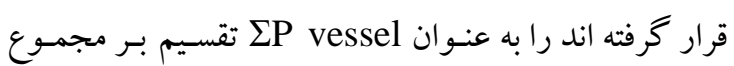

در مسير هييوتالاموس- هييوفيز-گوناد مىباشد (rا، I)). كونادوترويين يائسخى انسانى (Menopausal human (Gonadotropin; hMG مثلى به كار مىرود؛ و تركيبات آن شامل گونادوترويين

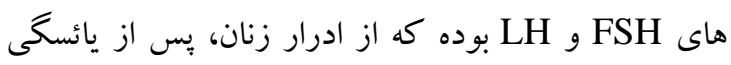

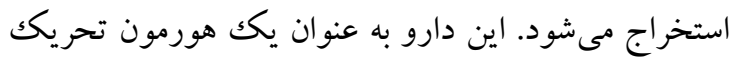

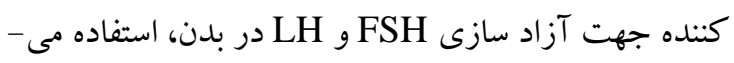

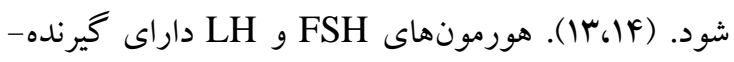
هاى اختصاصى در دستكاه توليد مثل مىباشند. هورمون

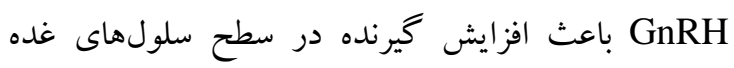

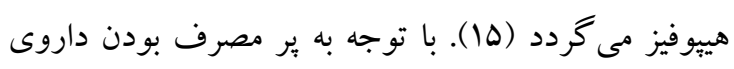

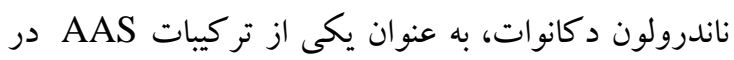

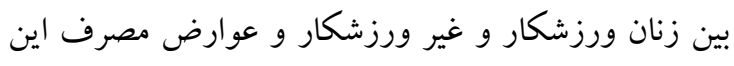

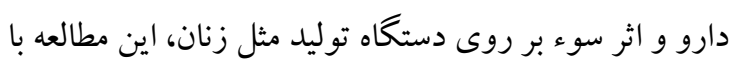

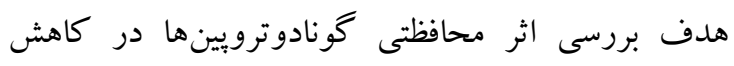
اثرات زيان بار اين دارو بر ساختار بافتى تخمدان انجام شد.

\section{مواد و روش ها}

اين تحقيق، يكك مطالعه تجربه ای مى باشد؛ كه در سال

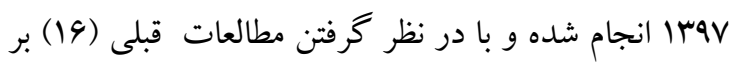

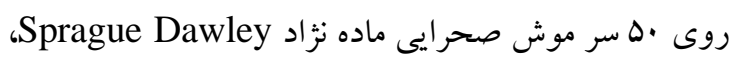

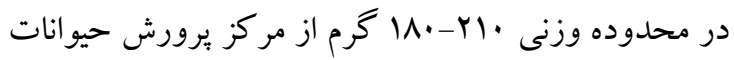

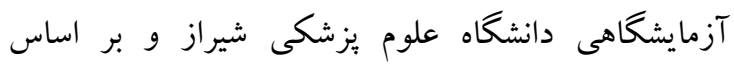

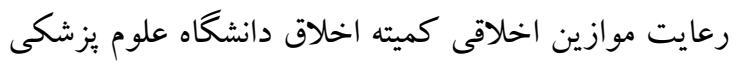

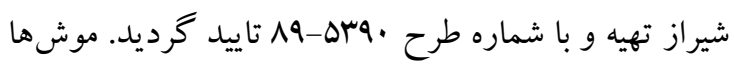
در قفسهاى جداكانه و در شرايط استاندارد (Y (Y ساعت

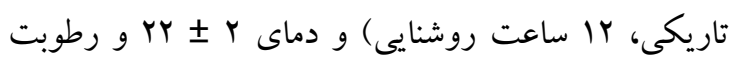

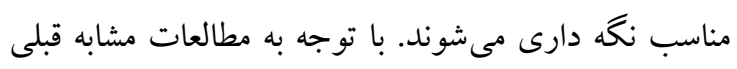

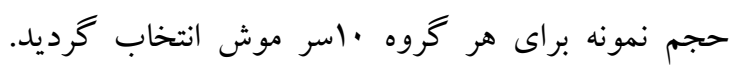

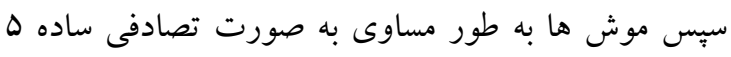

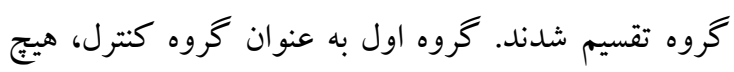

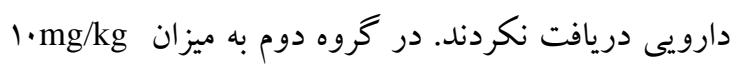
داروى ناندرولون دكانوات به صورت داخل صفاقى به 


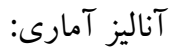

با استفاده از روش Kruskal-Wallis non-parametric test

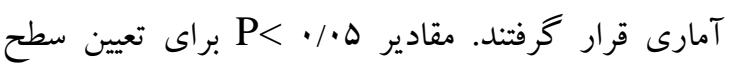

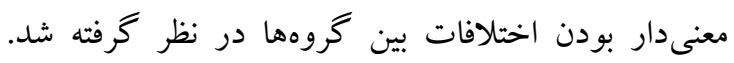
جهت رسم نمودار از نرم افزار Prism استفاده شد.
نقاطى كه روى كل بافت تخمدان افتاده است( (SP ovary) كرده، و سِّ عـدد بدست آمـده در حجـم كـل تخمـدان

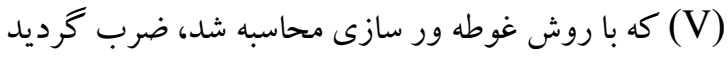

$\mathrm{V}_{\mathrm{v}}=\Sigma \mathrm{P}$ vessel $/ \Sigma \mathrm{P}$ ovary

$\mathrm{V}_{\text {total }}=\mathrm{Vv} \times \mathrm{V}$

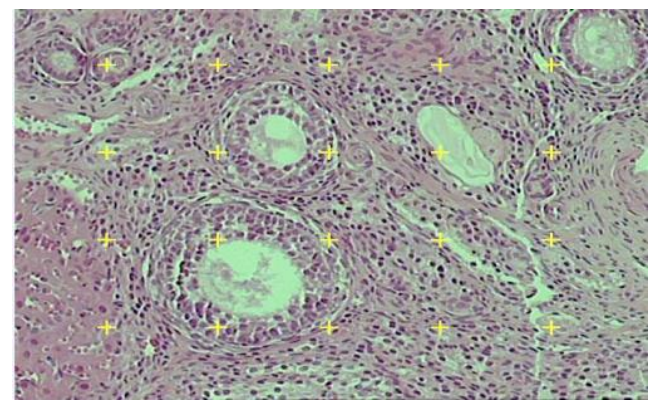

شكل 1. برش بافت تخمدان و يروب شمارش نقطه اى (Point probe)

ردههاى طبيعى فوليكولهاى تخمدان مشاهده شد. همجنين ميزان عروق خونى بيشتر شده و فوليكولهاى كيستيك كمترى در مقايسه با گروهى كه فقط داروى ناندرولون دريافت كرده بودند، مشاهده شد (شكل r ج). در مطالعه بافت شناسى تخمدان و حجم عروق خونى، در گروهى كه فقط داروى hMG دريافت كرده بود، و همجنين در گروه هاى كنترل و شم ، تغيير خاصى مشاهده نشد. تخمين حجم عروق خونى: مطالعات استريولوزى بافت تخمدان، نشان داد كه ميانگين حجم كل عروق خونى در تخمدان، در گروهى كه داروى باف ناندرولون دكانوات را به ميزان mg/kg ا دريافت كرده تردي بودند، در مقايسه با گروه شم افزايش معنى دارى داشت

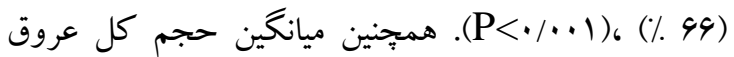
خونى در گروهى كه داروى ناندرولون دكانوات را به ميزان

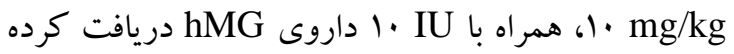
بودند، در مقايسه با گروه شم، افزايش معنى دارى مشاهده

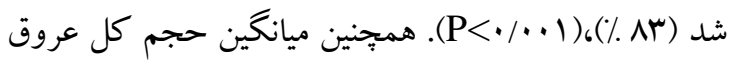

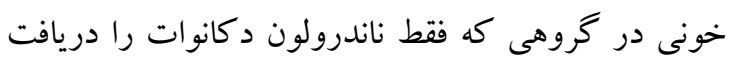

يافتهها مطالعه بافت شناسى برشهاى بافت تخمدان موش صحرايى در گروههاى شاهد و كنترل نشان دهندهى وجود تمام ردههاى طبيعى فوليكولهاى تخمدان به همراه جسم زرد مىباشد؛ و سلولهاى گر انولوزا (Corpus luteum; CL) (Granulosa cell; GC) بودند. در اين بررسى، هيجگگ نه فوليكول كيستيك، مشاهده نشد (شكل Y الف). بررسى بافت شناسى بافت تخمدان در

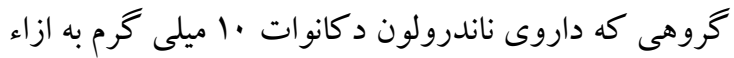
وزن، دريافت كرده بودند، نسبت به گروههاى شاهد، تعدادى جسم زرد به همراه تعدادى ردههاى طبيعى فوليكولهاى تخمدان مشاهده شد. همجِين ميزان عروق خونى به خصوص در بخش مر كزى تخمدان به ميزان زياد، و به مقدار كم در بخش قشرى، ديده شد. در اين بررسى، فوليكولهاى كيستيك (follicle; CF Cystic) در مقايسه

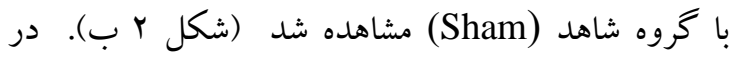

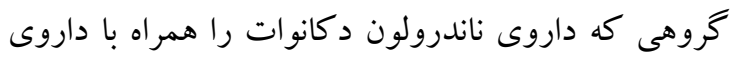

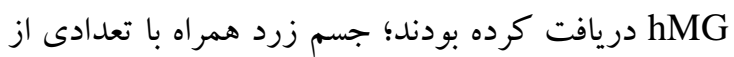




\section{كرده بودند، در مقايسه با گروهى كه اين دارو را همراه با (نمودار )

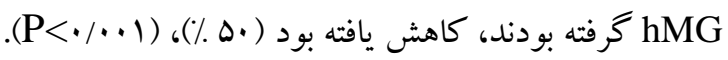
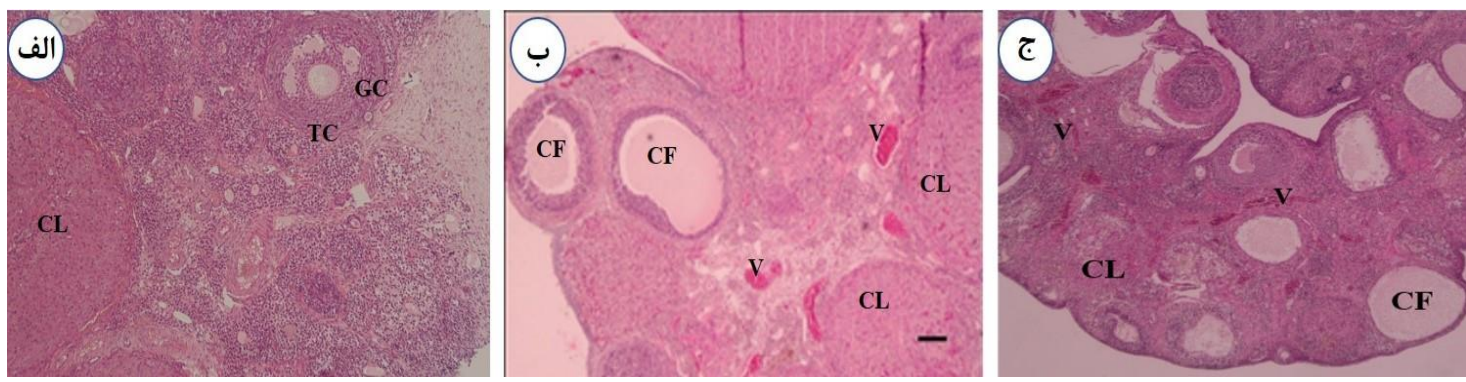

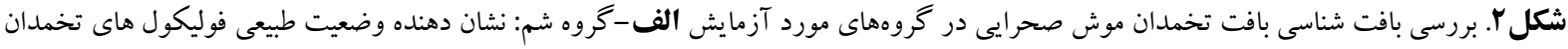

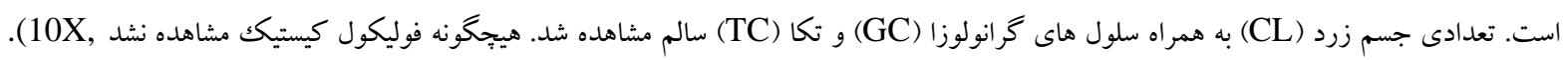

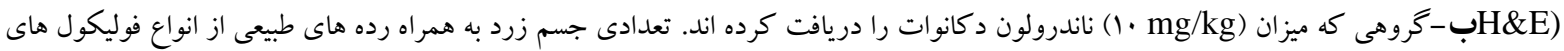

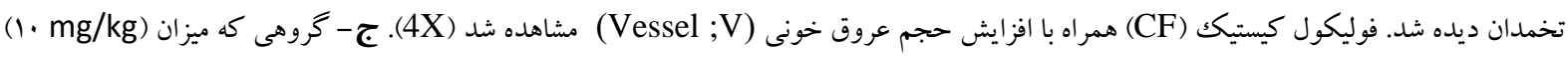

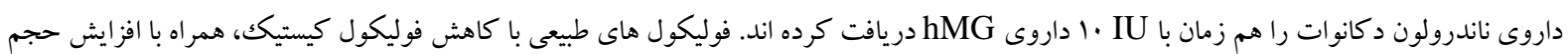

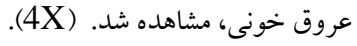

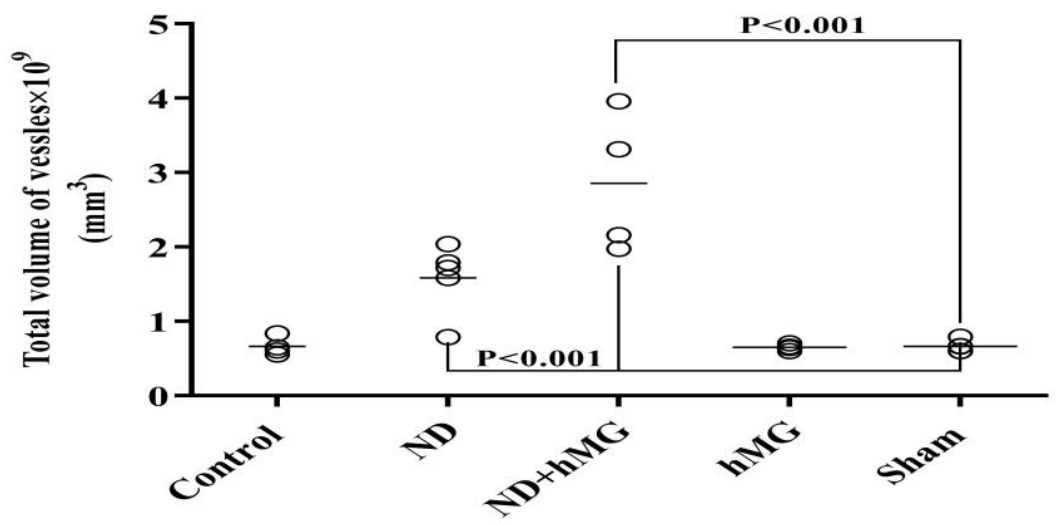

نمودار ا: ميانكين حجم كل عروق خونى در بافت تخمدان، در كروه هاى مورد بررسى

تخمــان مـوش صـحر ايى بـه دنبـال مصـرف اسـتروئيد،

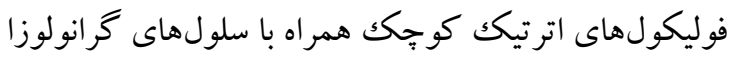
تحقيقـات نشـان داده انسد كـه مصـرف تر كيبـات حساوى

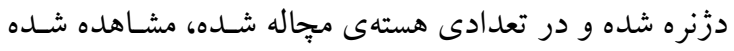

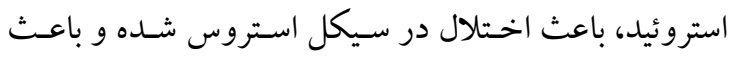
بود. سـلولهـاى تكـاى داخلـى در اطراف فوليكـولهـاى القاء تشكيل كيست تخمـدان در مـوش صحرايى مسى نـود. مرحلهى حفرهاى و بيش از تخمكك كذارى، دجار افزايش تأثير تر كيبات AAS بر روى محور هييوفيزى-كوناد، باعث

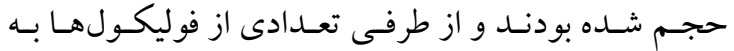
اختلال در هورمونهاى جنسى و ايجاد كيست در تخمـدان

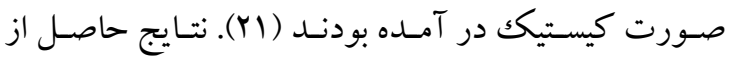

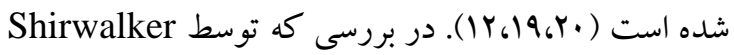
بررسى حاضـر نشـان داد كـه داروى نانـــرولون دكـانوات

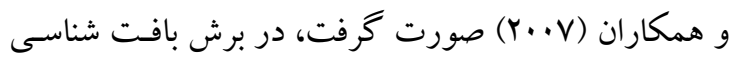


مطالعات، مطابقت داشت (YY). در اين تحقيق نشان داده شد

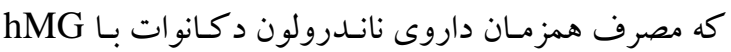

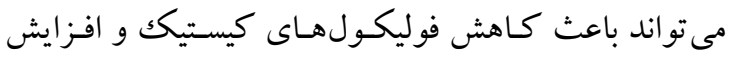
حجم عروق خونى شود. به نظر مىرسد كه داروى hMG با بولئ

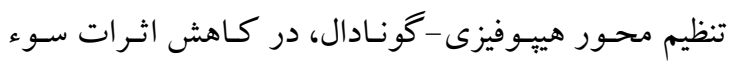

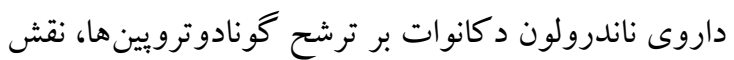
داشته باشد و باعث كاهش فوليكولهاى كيستيك مى گر ددد.

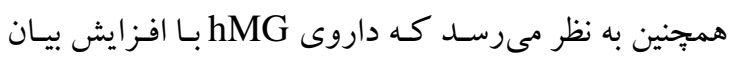

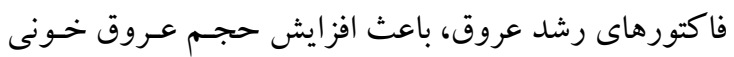

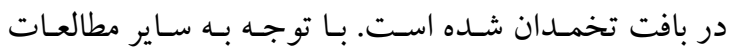

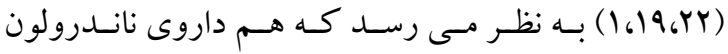

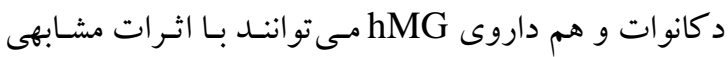
باعث افزايش حجم عروق خونى در بافت تخمدان شوند.

\section{نتيجه كيرى} با توجـه بـه مطالعهى حاضـر، داروى نانـدرولون دكانوات

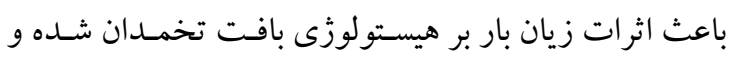
همجنين باعث افزايش حجم عروق خونى تخمدان مىشود. اين مطالعه نشان داد كه داروى hMG از طريق تنظيم ترشح

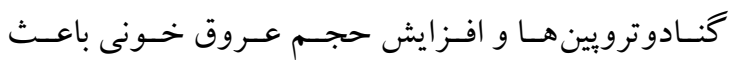
جلو گيرى از تغييرات هيستولوزيكك بافت تخمدان، به دنبـال مصرف داروى ناندرولون دكانوات مى شود.

\section{تشكر و قدردانى}

اين مطالعه بر كرفته از طرح تحقيقاتى مصوب دود دانشكاه علوم

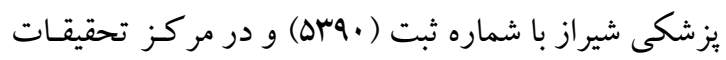

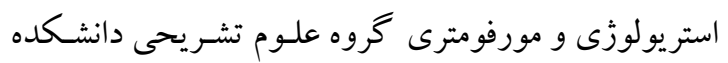

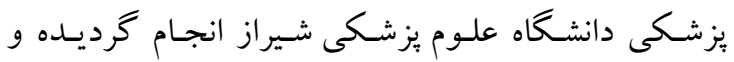

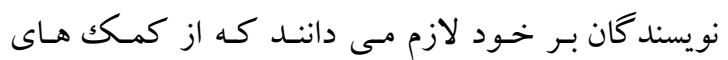
كارشناسان اين مر كز تشكر و سباسگزارى نمايند.
باعث تغييرات بافتى و القاء تشكيل كيست در تخمدان موش صحر ايى مىشود. بـه نظر مسى رســ كـه، اخستلال در سـنتز

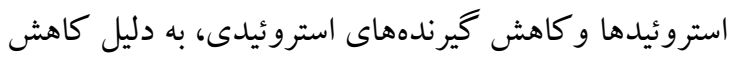

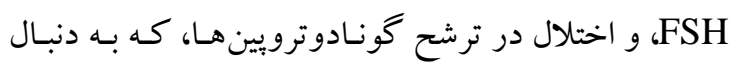
مصـرف داروى نانسـرولون دكـانوات ايجـاد مسى شـود، در تشكيل كيست نقش دارند. با توجه به نتيجه اين تحقيق مى -

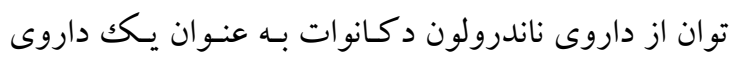

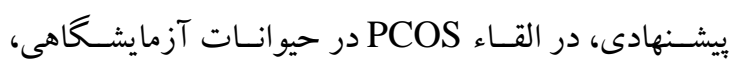
جهت مطالعات آينده استفاده كرد. Guzzoni و همكاران

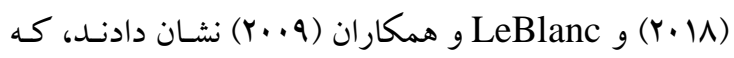
تركيبات استروئيدى از جمله اسـتروزن بـا افزايش نيتريكك اكسيد در اندوتليوم عروق، و كاهش آنزيم سيكلواكسيزناز، باعث اتساع عـروق در تخمـدان مـوش صسحر ايى مسى شعود. همجنــين داروى نانسـدرولون دكــانوات باعــث تغييــر در

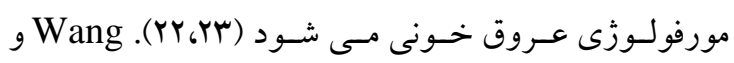

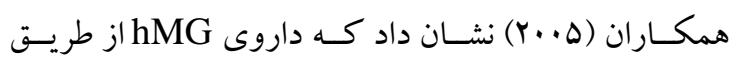
افزايش بيان فاكتور رشد اندوتليوم عروق خونى (VEGF)، باعث افزايش خونرسانى بـه فوليكـولهـا و رشـــ آن هـا در

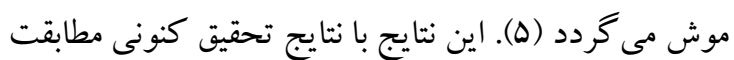

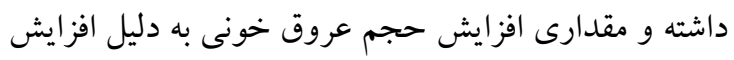
خونرسانى به بافت تخمدان مشاهده شد. در مطالعهى حاضر نشان داده شد كه، حجم عروق خونى در بافت تخمدان، بـه

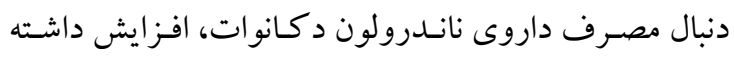
است. به احتمال زياد، داروى ناندرولون دكانوات نيـز ماننـد

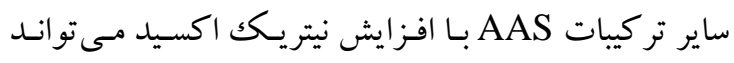

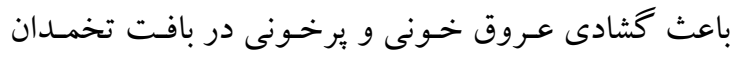

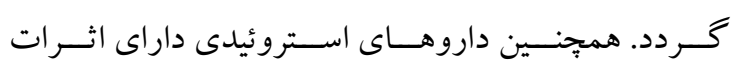

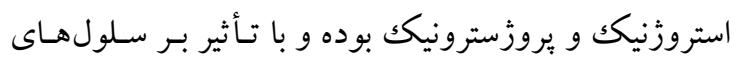

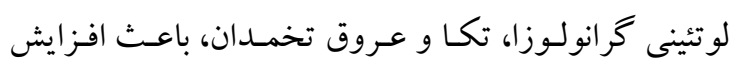

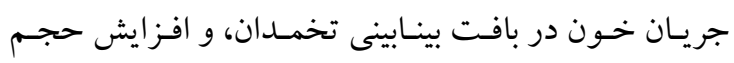
عـروق خـونى مسىشـوند. نتـايج ايـن تحقيـق بـا نتايج سـاير 
1. Simão VA, Berloffa Belardin L, Araújo Leite GA, de Almeida Chuffa LG, Camargo IC. Effects of different doses of nandrolone decanoate on estrous cycle and ovarian tissue of rats after treatment and recovery periods. Int J Exp Pathol. 2015; 96(5): 338-34.

2. Kevin M, Medical G, Delisi M, Wright p. Anabolic androgenic steroid use and involvement in viodent behavior in a nationally representative sample of young adult males in United States. J Public Health. 2008; 98: 2185-87.

3. Harmer PA. Anabolic androgenic steroid use among young male and female athletes: is the game to blam. Br J Sports Med. 2010; 44(1): 26-31.

4. Arnault E, Tosca L, Courtot AM, Doussau M, Pesty A, Finaz C. Caspase-2(L), caspase-9, and caspase-3 during in vitro maturation and fragmentation of the mouse oocyte. Dev Dyn. 2008; 237(12): 3892-903.

5. Wang y, Newton H, Jenny A, Spaliviero Charles M, Allan Marshan B, David J. Gonadotropin control of inhibin secretion and the relationship to follicle type and number in the hph mouse. Biol Reprod. 2005; 73(4): 610-18.

6. Almeida Chuffa LG, Souza RB, Frei F, Paccola Mesquita S, Camargo IC. Nandrolone decanoate and physical effort: histological and morphometrical assessment in adult rat uterus. ANAT REC. 2011; 294(2):335-41.

7. Mobini Far HR, Agren G, Lindquist AS, Marmendal M, Fahlke C, Thiblin I. Administration of the anabolic androgenic steroid nandrolone decanoate to female rats causes alteration in the morphology of their uterus and a reduction in reproductive capacity. Eur $\mathbf{J}$ Obstet Gynecol Reprod Biol. 2007; 131(2): 189-97.

8. Cherici Camargo IC, Barreiros de Souza R, de Fátima Paccola Mesquita S, Chuffa LG, Frei F. Ovarian histology and follicular score in female rats treated with nandrolone decanoate and submitted to physical effort. Acta Biol Hung. 2009; 60(3):253-61.

9. Karbalay-Doust S, Noorafshan A. Stereological estimation of ovarian oocyte volume, surface area and number: application on mice treated with nandrolone decanoate. Folia Histochemical ET Cytobiological J. 2012; 5:275-9.

10. Anthony J, Michael C, John H. Anabolic androgenic steroids: Medical assessment of present, past and potential users.2000; 173: 322-27.

11. Patanè FG, Liberto A, Maria Maglitto AN, Malandrino P, Esposito M, Amico F, et al. Nandrolone Decanoate: Use, Abuse and Side Effects. Medicina. 2020; 56(11):606.

12. Van Breda E, Keizer HA, Kuipers H, Wolffendbuttel BH. Androgenic anabolic steroid use and server hypothalamic- pituitary dysfunction. Sports Med. 2003; 24(3):195-6.

13. Goodman \& Gilman's. The pharmacological basis of therapeutics. 12th Ed. Bible: 2011; 1597-1652.

14. Schoenwolf, Gary C. II. Larsen, William J. Human embryology. 4th Ed. Churchill Livingstone; 2009; 28-50.

15. Janjic MM, Prévide RM, Fletcher PA, Sherman A, Smiljanic K, Abebe D, et al. Divergent expression patterns of pituitary gonadotropin subunit and GnRH receptor genes to continuous GnRH in vitro and in vivo. Sci Rep. 2019;9(1):20098.

16. Bordbar H, Mesbah F, Talaei T, Dehghani F, Mirkhani H. Modulatory effect of gonadotropins on rats' ovaries after nandrolone decanoate administration: a stereological study. Iran J Med Sci. 2014; 39(1):44-50.

17. Mesbah F, Bordbar H, Talaei Khozani T, Dehghani F, Mirkhani H. The non-preventive effects of human menopausal gonadotropins on ovarian tissues in Nandrolone decanoate- 
treated female rats: A histochemical and ultra-structural study. Int J Reprod Biomed. 2018; 16(3):159-174.

18. Charleston J.S, Hansen K.R, Thyer A.C, Charleston L.B, Gougeon A, Siebert J.R, et al. Estimating human ovarian non-growing follicle number: the application of modern stereology techniques to and old problem. Hum Reprod. 2011; 26(1).

19. Kafali H, Iriadam M, Osaradai I, Demir N. Induced poly cystic ovaries in the rat: A new modle for cystic ovarian disease. Arch Med Res. 2004; 35: 103-8.

20. Sotomayor-Zarate R, Tiszavari M, Cruz G, Lara HE. Neonatal exposure to single dose of estradiol or testosterone programs ovarian follicular development modified hypothalamic neurotransmitters and causes polycystic ovary during adulthood in the rat. Fertility Sterility J. 2011; 96: 1490-96.

21. Shirwalker H, Deepak NM., Anurupa M. Exposure of adult rats to estradiol valerate induces ovarian cyst with early senescence of follicles. Molecular Cellular Endocrinol. 2007; 272: 22-37.

22. Guzzoni V, Cunha TS, das Neves VJ, Briet L, Costa R, Moura M, et al. Nandrolone combined with strenuous resistance training reduces vascular nitric oxide bioavailability and impairs endothelium-dependent vasodilation. Steroids. 2018; 131:7-13.

23. LeBlanc Amanda J, Reyes R, Kang LS, Dailey RA, Stallone JN, Moningka NC, et al. Esterogen replacement restores flow-induced vasodilation in coronary arterioles of aged and ovariectomized rats. Physiol. 2009; 2: 125-8. 